\title{
Microhabitat Preferences of six Drosera (Droseraceae) from Tibagi River Basin, Paraná State, Brazil
}

\author{
Dennis Panayotis Saridakis ${ }^{1,3}$, José Marcelo Domingues Torezan ${ }^{2 *}$ and Galdino Andrade $^{3}$ \\ ${ }^{1}$ Departamento de Agronomia; Universidade Estadual de Londrina; 86051-970; Londrina - PR - Brazil. \\ ${ }^{2}$ Laboratório de Biodiversidade e Restauração de Ecossistemas; Universidade Estadual de Londrina; C. P. 6001; \\ 86051-970; Londrina - PR - Brazil. ${ }^{3}$ Laboratório de Ecologia Microbiológica; Universidade Estadual de \\ Londrina; andradeg@uel.br; C. P. 6001; 86051-970; Londrina - PR - Brazil.
}

\begin{abstract}
We studied the microhabitats and the climatic requirements of six Drosera taxa, which occur in the subtropical grasslands of the Tibagi river basin. They are annual,or most communly, perennial herbs known as carnivorous plants, whose leaves are transformed into traps for the capture and digestion of small insects as an adaptation for supplying nutricional deficiencies. They usually occur in distrophic substrata. In order to contribute to conservation plans for the species of the genus, threatened by the conversion of the natural grasslands into pastures, we tried to define their preferential habitats and climatic requirements. We verified that the variables of microhabitat and altitude presented significant correlation at 5\% probability level, while the variables in annual average relative humidity, annual average temperature and type of substratum types did not show significant correlation.
\end{abstract}

Key words: Ecology, carnivorous plants, Drosera, sundew, Brazil, Tibagi River Basin

\section{INTRODUCTION}

Drosera L., as well as other carnivorous plants genera such as Utricularia and Genlisea, inhabit humid soils that are poor in nutrients and are often exposed to full sun (Juniper et al., 1989). The carnivorous plants are known for their capacity to attract, capture, digest and use the nutrients derived from their prey for their own benefit, in addition to their usual capacity to photosynthesize as any other green plant (Piliackas et al., 1989). According to Juniper et al. (1989), the carnivorous plants are included in 9 families and 19 genera, divided in approximately 500 species. Out of the 9 existent families, only 2 occur in the Tibagi river basin: Droseraceae and Lentibulariaceae. Of the 4 genera that compose the family Droseraceae, only the genus Drosera occurs in Brazil and in the Tibagi river basin (Saridakis, 1997). The genus is cosmopolitan with more than 100 dispersed species all over the world, reaching up to 16 taxa in Brazil (Silva, 1994). They are annual, or most commonly, perennial herbaceous dicotyledons, known in their occurence area as " orvalhinha" (Santos, 1980), specialized in insectivory, with their rosette-like leaves covered with glands and trichomes to form a lethal insect trap.

The Tibagi river basin encompasses an area of near $24,000 \mathrm{Km}^{2}$, corresponding to $12.5 \%$ of the surface of the Paraná state. The Tibagi river has its upstream in the south of the state and runs $550 \mathrm{~km}$ to the north. The vegetation in the south of the basin (higher Tibagi) is composed predominantly by natural grasslands, where several types of

\footnotetext{
* Author for correspondence
} 
associated environments which include rock outcrops, poorly-drained depressions and areas with sandy soil, forming countless microhabitats (Universidade Estadual de Londrina, 1991).

In this work, our goals were to produce a list of the Drosera taxa in the study area, to define the necessary environmental conditions for the occurrence of each taxon and to measure the correlation degree among taxa and the environmental variables. Ellison and Gotelli (2001) suggested that modern research aproaches on carnivorous plants should guide conservation and managment strategies for these plants, increasingly threatened by overcollecting, habitat destruction and environmental change. We hope to contribute our data of the preferential habitats of Drosera in the future conservation plans of the subtropical grasslands of the Paraná state, which is increasingly being turned over to pastures and agriculture.

\section{MATERIAL AND METHODS}

Sampling was undertaken in eight points, during the period from 1995 to 1997 . Fertile plants were also collected for the inclusion in the FUEL herbarium (Fundação Universidade Estadual de Londrina), following the basic methodology for botanical sample preparation (Fidalgo and Bononi, 1989). Studies of climatic charts (Paraná, 1987; Paraná, 1994), for each location point, established data for altitude, annual average temperature and annual average relative humidity (RH), which were logged. We also logged, after field observations, data relating to the substratum (i.e. texture and apparent amount of organic matter) and microhabitats of each taxon (i.e. microtopography and water disponibility).

Besides our own samples, we rewiewed materials from other collectors deposited in the herbaria FUEL, MBM (Museu Botânico Municipal Curitiba) and UEPG (Universidade Estadual de Ponta Grossa), in order to collect data about the species distribution and reported environmental preferences inside the study area. From herbaria collections we obtained data of 2 additional location points (points 9 and 10), from which no consistent information about the substratum and microhabitat was available. The identification of each species of the studied plants was accomplished through the analysis of both live and dried specimens and on related bibliography (Radford, 1974; Santos, 1968, 1980,1989; Silva, 1994).

The data relating to altitude, annual average relative humidity and annual average temperature were ranked from the lowest to the highest values. Substratum categories were ranked according to their granulometry and organic matter content, beeing: 1 - clay, 2 - sand, 3 - moss, peat and sand, 4 - peat, 5 - moss and peat, 6 - moss. Microhabitat categories were ranked according to their drainage and inferred hipoxy conditions, beeing: 1 - poorlydrained depressions, 2 - plateaus at lake margins + beach at riverside, 3 - riverside, 4 - wet slopes at riverside, 5 - wet slopes, 6 - wet slopes at riverside + rock outcrops at riverside, 7 - wet slopes with superficial water flow + rock outcrops with superficial water flow.

We used a non-parametric statistical treatment, the Spearman Rank Correlation (Rs), appropriate for the qualitative data used in this study, which allowed the association between the occurrence of the Drosera taxa and the environmental variables.

\section{RESULTS}

Through data obtained with our own samplings, in consultations to herbaria and in specific bibliography (Santos, 1980; Silva, 1994), the geographical distribution of the known Drosera species from the Tibagi river basin was obtained (Fig.1). From 10 location points, 22 occurrences of the genus were obtained, of which 4 species and 2 undescribed taxa were identified. Environmental data is presented in Table 1 , in which all the variables are given for the taxa in each sampling point. The data obtained from the statistical analysis are presented in Table 2, where it is demonstrated that out of the 5 variables analyzed, only 2 (microhabitat and altitude) reject the null hypothesis, indicating significant correlation (Rs) at the level of 5\% probability, being their $\mathrm{p}$ value 0.032794 and 0.005361 , respectively. 


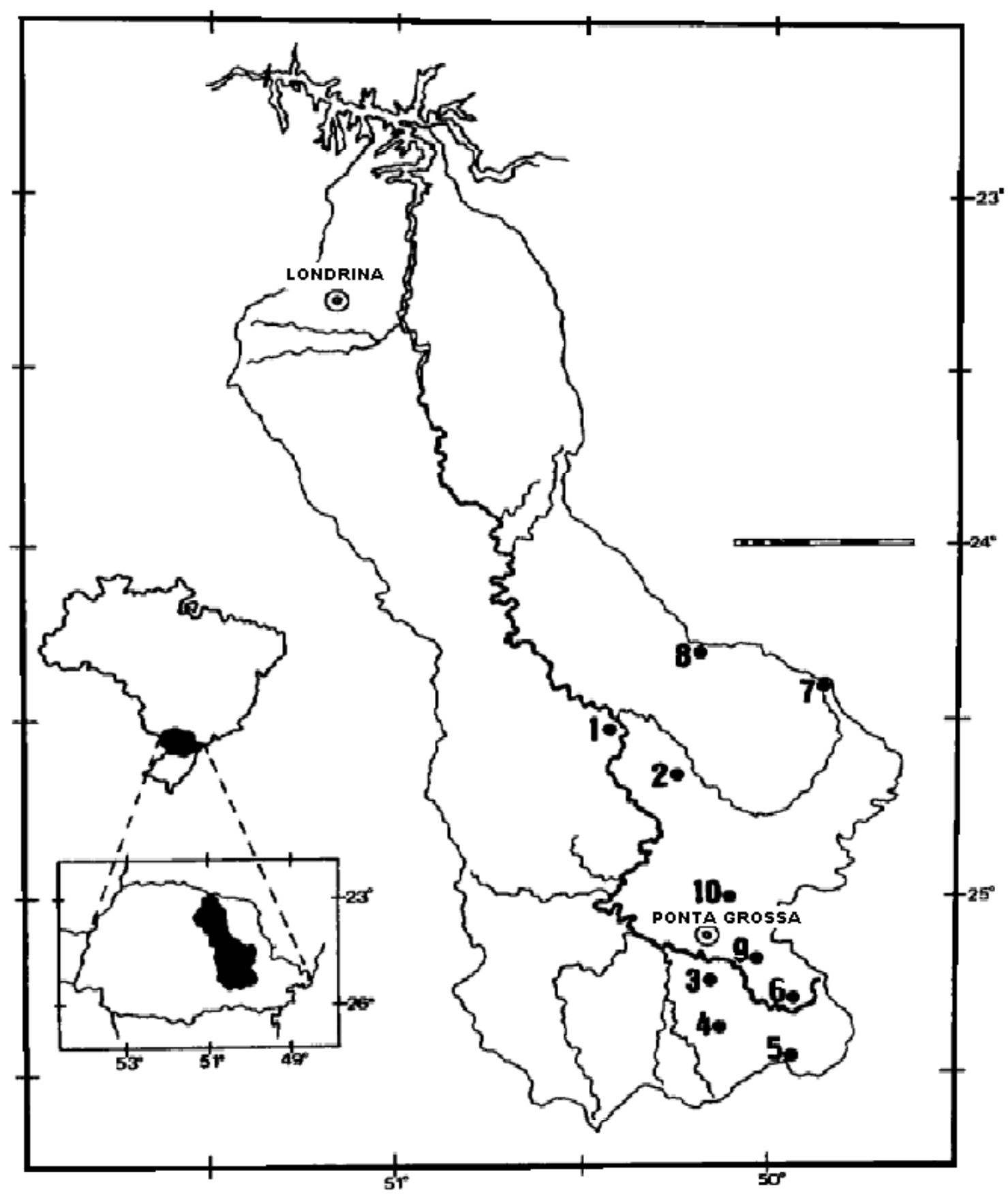

Figure 1 - Tibagi river basin with all occuring Drosera taxa and location sampling points distribution. 
Table 1 - Sampling location points of the six Drosera taxa and their preferred environmental and habitat requirements from Tibagi river basin.

\begin{tabular}{|c|c|c|c|c|c|c|c|}
\hline $\begin{array}{c}\text { Location } \\
\text { Sampling } \\
\text { point }\end{array}$ & $\begin{array}{c}\text { Municipal } \\
\text { district }\end{array}$ & $\begin{array}{c}\text { Táxon } \\
\text { or } \\
\text { Taxa } \\
\text { Present }\end{array}$ & Substratum & Microhabitat & $\begin{array}{l}\text { Altitude } \\
(\mathbf{m})\end{array}$ & $\begin{array}{c}\text { Annual } \\
\text { average } \\
\text { relative } \\
\text { humidity } \\
(\%)\end{array}$ & $\begin{array}{c}\text { Annual } \\
\text { average } \\
\text { temperature } \\
\left({ }^{\circ} \mathrm{c}\right)\end{array}$ \\
\hline \multirow[b]{2}{*}{1} & \multirow[b]{2}{*}{ Tibagi } & $\begin{array}{l}\text { D. brevifolia } \\
\text { Pursh. }\end{array}$ & sand & riverside & \multirow[b]{2}{*}{700} & \multirow[b]{2}{*}{80} & \multirow[b]{2}{*}{18.5} \\
\hline & & $\begin{array}{l}\text { D. communis } \\
\text { A. St.- Hil. }\end{array}$ & moss & riverside & & & \\
\hline \multirow[b]{2}{*}{2} & \multirow[b]{2}{*}{ Tibagi } & $\begin{array}{l}\text { D. communis } \\
\text { A. St.- Hil. }\end{array}$ & moss & $\begin{array}{l}\text { rock outcrops at } \\
\text { riverside }\end{array}$ & \multirow[b]{2}{*}{900} & \multirow[b]{2}{*}{82} & \multirow[b]{2}{*}{18} \\
\hline & & $\begin{array}{c}\text { D. villosa var. } \\
\text { villosa A. } \\
\text { St.- Hil }\end{array}$ & moss & $\begin{array}{l}\text { rock outcrops at } \\
\text { riverside }\end{array}$ & & & \\
\hline \multirow[t]{2}{*}{3} & \multirow{2}{*}{$\begin{array}{l}\text { Ponta } \\
\text { Grossa }\end{array}$} & $\begin{array}{l}\text { D. brevifolia } \\
\text { Pursh. }\end{array}$ & sand & beach at riverside & \multirow[t]{2}{*}{800} & \multirow[t]{2}{*}{77} & \multirow[t]{2}{*}{17.5} \\
\hline & & $\begin{array}{l}\text { D. communis } \\
\text { A. St.- Hil. }\end{array}$ & moss & riverside & & & \\
\hline \multirow[b]{2}{*}{4} & \multirow[b]{2}{*}{ Palmeira } & $\begin{array}{l}\text { D. brevifolia } \\
\text { Pursh. }\end{array}$ & clay & $\begin{array}{c}\text { wet slopes with } \\
\text { superficial water flow }\end{array}$ & \multirow[b]{2}{*}{900} & \multirow[b]{2}{*}{77} & \multirow[b]{2}{*}{18} \\
\hline & & $\begin{array}{l}\text { D. communis } \\
\text { A. St.- Hil. }\end{array}$ & peat & $\begin{array}{l}\text { poorly-drained } \\
\text { depressions }\end{array}$ & & & \\
\hline 5 & Palmeira & $\begin{array}{l}\text { D. brevifolia } \\
\text { Pursh. }\end{array}$ & sand & $\begin{array}{c}\text { plateaus at lake } \\
\text { margins }\end{array}$ & 900 & 82 & 17 \\
\hline \multirow{4}{*}{6} & \multirow{4}{*}{ Palmeira } & $\begin{array}{l}\text { D. brevifolia } \\
\text { Pursh. }\end{array}$ & clay & wet slopes at riverside & \multirow{4}{*}{900} & \multirow{3}{*}{82} & \multirow{3}{*}{17} \\
\hline & & $\begin{array}{l}\text { D. communis } \\
\text { A. St.- Hil. }\end{array}$ & moss & $\begin{array}{l}\text { poorly-drained } \\
\text { depressions }\end{array}$ & & & \\
\hline & & $\begin{array}{c}\text { D.villosa var. } \\
\text { villosa A. } \\
\text { St.- Hil. }\end{array}$ & peat & wet slopes at riverside & & & \\
\hline & & D. sp1 & moss & $\begin{array}{c}\text { rock outcrops with } \\
\text { superficial water flow }\end{array}$ & & \multirow{6}{*}{80} & \multirow{6}{*}{17.5} \\
\hline \multirow{5}{*}{7} & \multirow{5}{*}{$\begin{array}{l}\text { Piraí do } \\
\text { Sul }\end{array}$} & $\begin{array}{l}\text { D. communis } \\
\text { A. St.- Hil. }\end{array}$ & moss and peat & $\begin{array}{l}\text { poorly-drained } \\
\text { depressions }\end{array}$ & \multirow{5}{*}{1100} & & \\
\hline & & $\begin{array}{l}\text { D. montana } \\
\text { var. montana } \\
\text { A. St.- Hil }\end{array}$ & sand & wet plateaus & & & \\
\hline & & $\begin{array}{l}\text { D. villosa var. } \\
\text { villosa A. } \\
\text { St.- Hil }\end{array}$ & $\begin{array}{l}\text { moss, peat } \\
\text { and sand }\end{array}$ & $\begin{array}{l}\text { wet slopes and poorly- } \\
\text { drained depressions }\end{array}$ & & & \\
\hline & & D. sp1 & moss & $\begin{array}{c}\text { rock outcrops with } \\
\text { superficial water flow }\end{array}$ & & & \\
\hline & & D. $\mathrm{sp} 2$ & $\begin{array}{l}\text { moss, peat } \\
\text { and sand }\end{array}$ & $\begin{array}{l}\text { poorly-drained } \\
\text { depressions }\end{array}$ & & & \\
\hline
\end{tabular}




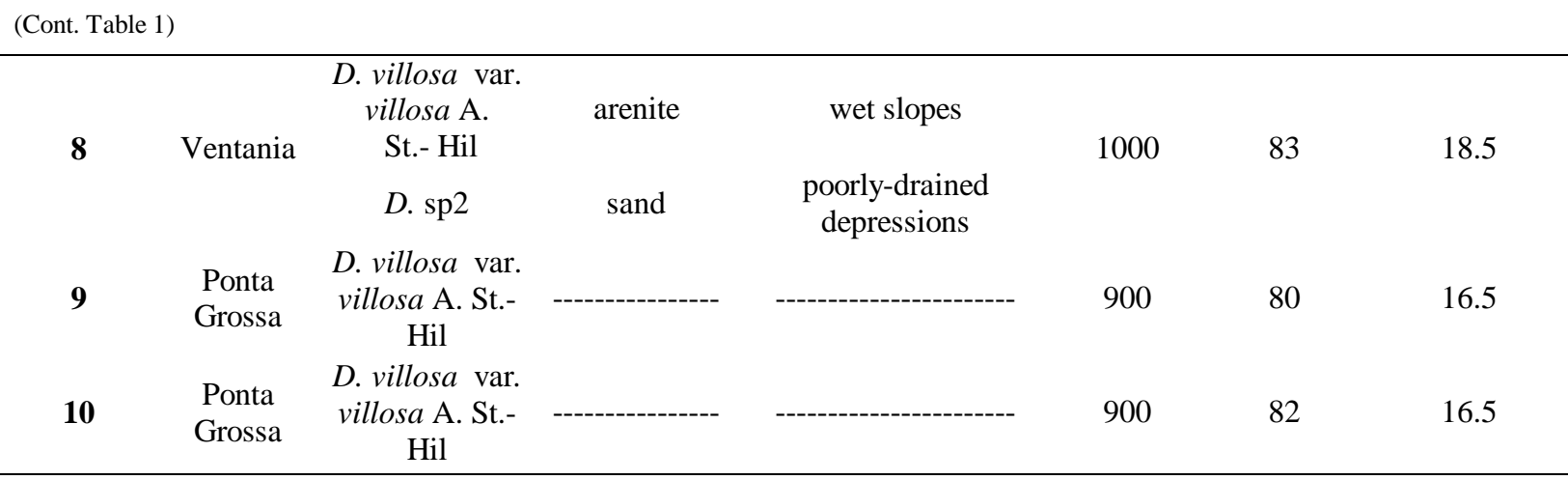

Table 2 - Spearman Rank Correlation between Drosera taxa from Tibagi river basin and selected environmental variables

\begin{tabular}{l|lr|r|r}
\hline \multicolumn{1}{c|}{ Envorinmental variable } & N & \multicolumn{1}{c|}{$\mathbf{R}_{\mathbf{s}}$} & \multicolumn{1}{c}{$\mathbf{t}(\mathbf{N}-2)$} & p value \\
\hline Microhabitat & 20 & 0.874570 & 2.312397 & 0.032794 \\
Substratum & 20 & 0.228681 & 0.996623 & 0.332158 \\
Annual average relative humidity & 22 & 0.362097 & 1.737235 & 0.097723 \\
Annual average temperature & 22 & -0.073964 & -0.0331684 & 0.743578 \\
Altitude & 22 & 0.572509 & 3.122750 & 0.005361 \\
\hline
\end{tabular}

\section{DISCUSSION}

\section{Type of microhabitat}

In general, the habitats of the six studied Drosera are similar to that found in inselberg habitats (Seine et al., 1995; Dörrstock et al., 1996) in relation to the type of substratum, $\mathrm{pH}$ range (data not shown), microtopography and co-existing vegetation. It was observed that some of the Drosera taxa (D. villosa var. villosa, D. communis and $D$. sp2) inhabit more than one microhabitat. defined as a specialized habitat species that shelter a restricted number of organisms (Jones, 1997). The other taxa (e.g. D. brevifolia, D. sp1 and $D$. montana var. montana) were restricted to distinct or with little variation microhabitats, that were repeated in many sampling points. Thum (1986) observed clearly the occurence of different microhabitat preferences both by horizontal and vertical separation and by niche segregation between two sympatric Drosera species (Drosera rotundifolia L. and Drosera intermedia Hayne).

The correlation among these six Drosera and the type of preferred microhabitats was shown to be significant. We discovered that these microhabitats consisted of a complexity of factors. Water availability, water scapage and flow rates, available sunlight, habitat microtopography and soil combinations were some of the factors producing these unique microhabitats. The occurrence of the genus Drosera in nature is intimately related to nutrient poor soils. Plants are mostly exposured to full sunlight, and the reflection of the sunshine on the dew-like glicosaminoglicans droplets secreted by their glandular trichomes visually help to attract their preys (Pietropaolo and Pietropaolo, 1986; Piliackas et al., 1989 and Juniper et al., 1989). In agreement with Piliackas (1989), the water avaiability is very important for those plants, because besides the performance in the attraction and capture processes, it also participates in the production of the digestive enzymes that are secreted soon after the prey capture. Due to the high indexes of water evaporation in these secreted substances, due to their exposure to environment, these plants usually need a constant hydric supply.

\section{Type of substratum}

The type of substratum did not presented significant correlation with the identity of the studied taxa on its own, indicating that this data is only important in the overall arrangement of the microhabitat as a whole. Collected plants cultivated in different substrata from the original ones (e.g. Sphagnum moss plus sand), survived the cultivation and completed their life cycle (unpublished data). This suggests that, in a general 
way, the occuring Drosera taxa from the study area do not demand a very specific substratum to develop.

\section{Relative humidity}

In spite of the water availability to be an essential factor for the occurrence of Drosera, the variable annual average relative humidity did not present significant correlation in relation to the occurrence of those plants in the study area. This is due to the fact that, the climatic chart scale used in this present study was not able to represent the variations found in the microhabitats, or the obvious limitation of representing annual averages. In this way, the subtle but in wide spatial scale variations of $\mathrm{RH}$, obtained from the climatic charts did not serve as good descriptor of the preferential environments of the six Drosera, presenting poor occurence previsibility power.

The analysis of this variable depends on measures in finer scale, limiting its usefulness for mapping and conservation planning, since most of the geographical information systems (GIS) available cannot reach such fine scales.

\section{Annual average temperature}

This variable also did not present significant correlation, and therefore is not a good predictor, at least on its own, for the distribution of the studied plants, again in function of scale problems and of the inadequacy of the use of annual averages, that hide important variations such as the minimum and maximum absolute temperatures, and the frost frequency. Possibly the isolated use of those variables can yeld better results. Unfortunately, at present there is no availability of this type of information in graphic form, so that those suppositions could be tested.

\section{Altitude}

The minimum altitude observed for the occurrence of those plants in the study area was of approximately 700 meters, in the municipal district of Tibagi (Table 1). The correlation between this variable and the identity of the six Drosera was highly significant. This occurs because the altitude variation implicates in the change of many climatic variables, such as temperatures, frost frequency and sunshine availability (Walter, 1986). This result indicates that there exists a tendency separating these six Drosera studied in altitudinal ranges (Wilson and Lee, 1994), and that the altitude is one of the important variables to establish their distribution. Most of GIS's can manipulate information on altitude in an appropriate scale.

\section{CONCLUSIONS}

We concluded that the distribution of these six Drosera is limited to the areas of higher and medium Tibagi, to sunny habitats, in altitudes above 700 meters. These areas are characterized by low grasslands, with many small wet depressions, arenitic rock outcrops and streams and little rivers without marginal forest vegetation.

The four species and two indeterminated Drosera taxa (probably new species) that occur at the subtropical grasslands of the Tibagi river basin occupy several microhabitats, as small poorlydrained depressions, sandy plateaus, lakes and rivers margins and wet slopes. For their appropriate conservation it is necessary to protect these places from the development of pastures or agriculture. Using GIS as a starting point, it will be possible to establish which areas (potentally under treat from development) have a high probability of Drosera occurance. Field surveys can then be undertaken to establish areas of importance for conservation protection.

\section{RESUMO}

Nós estudamos os microhabitats e as exigências climáticas de seis taxa de Drosera (Droseraceae), que ocorrem nos campos subtropicais da bacia do rio Tibagi. São ervas perenes, conhecidas como plantas carnívoras, cujas folhas são transformadas em armadilhas para a captura e digestão de pequenos animais, o que tem sido referido como adaptação para suprir deficiências nutricionais, já que geralmente ocorrem em substratos distróficos. Para auxiliar na elaboração de planos de conservação para as espécies do gênero, ameaçadas pela conversão dos campos em pastagens, nós procuramos definir os habitats preferenciais e as exigências climáticas. Verificouse que as variáveis: tipo de microhabitat e altitude apresentam correlação significativa no nível de $5 \%$, enquanto as variáveis: umidade relativa média anual, temperatura média anual e tipo de substrato, não apresentaram correlação significativa. Os resultados obtidos sugerem que a distribuição dos 
taxa de Drosera estudados está relacionada principalmente com a variação de altitude e o tipo de microhabitat.

\section{REFERENCES}

Ellison, A. and Gotelli, J. (2001), Evolutionary ecology of carnivorous plants, Trends in Ecology and Evolution, 11 : (16), 623 - 629.

Dörrstock, S.; Porembski, S. and Barthlott, W. (1996), Ephemeral flush vegetation on inselbergs in ihe Ivory Cost (West Africa). Candollea, 51 : (2), 407-419.

Fidalgo, O. and Bononi, V. L. (coords.) (1989), Técnicas de coleta, preservação e herborização de material botânico. São Paulo : Instituto de Botânica. (Série documentos).

Jones, A. M. (1997), Environmental Biology. London : Routledge.

Juniper, B. E.; Robins, R. J. and Joel, D. M. (1989), The Carnivorous Plants. London : Academic Press.

Paraná. Governo do Estado. (1987), Atlas do Estado do Paraná. Curitiba : Secretaria do Estado, da Agricultura e do Abastecimento.

Paraná. Governo do Estado. (1994), Cartas Climáticas do Estado do Paraná. Instituto Agronômico do Paraná.

Pietropaolo, J. and Pietropaolo, P. (1986), Carnivorous Plants of the World. Portland : Timber Press.

Piliackas, J. M. and Barbosa, L M. (1989), Aspectos Biológicos e Ecológicos de Plantas Carnívoras. Ecossistema, 14, 89-103.

Pinto-Coelho, R. M. (2000), Fundamentos em Ecologia. Porto Alegre : Artes Médicas Sul.

Radford, A. E. (1974), Vascular plant systematics. New York : Harper and Row.

Santos, E. (1968), Droseraceae do Rio de Janeiro, Brasil. Boletim do Museu Nacional, 35.

Santos, E. (1980), Droseráceas. In: Reitz, R. (ed.). Flora ilustrada Catarinense: Herbário Barbosa Rodrigues, parte 1.

Santos, E. (1989), O gênero Drosera L. no Brasil 2: sobre D. Montana. St. Hil. Bradea, 5 : (21), 249-256.

Saridakis, D. P. (1997), Análise taxonômica e ecológica das plantas carnívoras da bacia do rio Tibagi-PR. Monografia (Bacharelado), Universidade Estadual de Londrina, Londrina, Paraná, Brasil.

Seine, R.; Porembski, S. and Barthlott, W. (1995), A neglected habitat of carnivorous plants: Inselbergs. Feddes Repert., 106 : (5-8), 555-562.
Silva, T. R. S. (1994), Estudos taxonômicos de Drosera L. (Droseraceae) do Brasil. Dissertação (Mestrado em Botânica). Instituto de Botânica, Universidade de São Paulo.

Thum, M. (1986), Segregation of habitat and prey in two sympatric carnivorous plants species, Drosera rotundifolia and Drosera intermedia. Oecologia, 70, 601-605.

Universidade Estadual de Londrina (1991), Aspectos da fauna e flora da bacia do rio Tibagi: relatório técnico-científico. Londrina : UEL. v. 2.

Walter, H. (1986), Vegetação e zonas climáticas. São Paulo : EPU.

Wilson, J. B. and Lee, W. G. (1994), Niche overlap of congeners: a test using plant altitudinal distribution. Oikos, 69, 469-475.

Received: January 22, 2002 ; Revised: July 29, 2003; Accepted: November 27, 2003. 